\title{
Spatial and temporal distribution of stream macroalgae in a tropical river basin
}

\author{
Aurélio Fajar Tonetto ${ }^{1}$, Cleto Kaveski Peres ${ }^{2}$, Rafael Taminato Hirata ${ }^{3}$ \& Ciro Cesar Zanini Branco ${ }^{4,5}$ \\ ${ }^{1}$ Universidade Paulista, Ciências Biológicas, Jundiaí, SP, Brazil. \\ ${ }^{2}$ Universidade Federal da Integração Latino-Americana, Departamento de Biologia, Foz do Iguaçu, \\ PR, Brazil. \\ ${ }^{3}$ Universidade de São Paulo, Departamento de Biologia, São Paulo, SP, Brazil. \\ ${ }^{4}$ Universidade Estadual Paulista, Ciências Biológicas, Assis, SP, Brazil. \\ ${ }^{5}$ Corresponding author: Ciro Cesar Zanini Branco,e-mail: czbranco@assis.unesp.br
}

TONETTO, A.F., PERES, C.K., HIRATA, R.T., BRANCO, C.C.Z. Spatial and temporal distribution of stream macroalgae in a tropical river basin. Biota Neotropica. 15(4): e0095. http://dx.doi.org/10.1590/ 1676-0611-BN-2015-0095

\begin{abstract}
Spatial and temporal distribution of stream macroalgae in streams from southeastern Brazil were assessed for one year. The fluctuations in macroalgal species composition and environmental factors were monitored monthly. The region exhibit a tropical climate, with defined rainy and dry seasons. Nineteen species were found, with a predominance of Chlorophyta (52.7\% of the species), followed by Cyanobacteria (26.3\%), Ochrophyta and Rhodophyta (10.5\% each). Scytonema arcangeli had the highest number of records (63.6\%), while Mougeotia capucina occurred in all sampling sites. Community structure had low similarity (20-26\%) and the environmental factors showed a weak contribution to the distribution pattern observed. Despite this, the light availability at the stream-bed seems to be a major influence on the macroalgal seasonal dynamics. We suggest that macroalgae communities are predominantly composed of rare species, and this could explain the lack of a clear spatial and temporal variation pattern of these organisms.
\end{abstract}

Keywords: species distribution, spatial variation, temporal dynamics, stream macroalgae, rarity

TONETTO, A.F., PERES, C.K., HIRATA, R.T., BRANCO, C.C.Z. Distribuição espacial e temporal de macroalgas de riachos em uma bacia tropical. Biota Neotropica. 15(4): e0095. http://dx.doi.org/10. 1590/1676-0611-BN-2015-0095

Resumo: A distribuição espacial e temporal das macroalgas lóticas em riachos do sudeste do Brasil foram avaliadas por um ano. As flutuações na composição de espécies de macroalgas e fatores ambientais foram monitorados mensalmente. A região apresenta um clima tropical, com estações chuvosas e secas definidas. Dezenove espécies foram encontradas, com predomínio de Chlorophyta (52,7\% das espécies), seguido por Cianobactérias (26,3\%), Ochrophyta e Rhodophyta (10,5\% cada). Scytonema arcangeli teve o maior número de registros (63,6\%), enquanto Mougeotia capucina ocorreu em todos os pontos de amostragem. A estrutura da comunidade teve baixa similaridade (20-26\%) e os fatores ambientais mostraram uma fraca contribuição para o padrão de distribuição observado. Apesar disso, a disponibilidade de luz no leito do riacho parece ser de grande influência sobre a dinâmica sazonal de macroalgas. Nós sugerimos que as comunidades de macroalgas são predominantemente compostas por espécies raras, e isso poderia explicar a falta de um padrão claro de variação espacial e temporal desses organismos.

Palavras-chave: distribuição de espécies, variação espacial, dinâmica temporal, macroalgas de riacho, raridade

\section{Introduction}

Stream macroalgae are important primary producers in many lotic environments and numerous investigations have focused on these organisms (Sheath \& Cole 1992, Branco \& Necchi Júnior 1996, Branco et al. 2009, Necchi Júnior et al. 2000, 2003, 2008, Peres et al. 2008). Their ecological distribution is influenced by oscillations in environmental factors. Rivers and streams can be characterized by a set of habitat descriptors, which can be divided into physicochemical variables (e.g. $\mathrm{pH}$, dissolved oxygen, temperature) and structural variables (e.g. marginal vegetation and substrate), both of which vary over time (Allan \& Castillo 2007).

The majority of studies on ecological distribution of macroalgal communities suggests several habitat variables that could be relevant to temporal variation including: temperature (DeNicola 1996, Branco et al. 2008, Bojorge-Garcia et al. 2010), current velocity (Uehlinger 1991, Stevenson 1996), nutrients (Borchardt 1996), day length, precipitation, turbidity and dissolved oxygen (Necchi Júnior \& Pascoaloto 1993, 
Table 1. Descriptions of sampling sites in the Cervo River Basin.

\begin{tabular}{|c|c|}
\hline Streams & Description \\
\hline $\begin{array}{l}\text { Site } 1 \text { - Barro Preto stream } \\
\left(22^{\circ} 35^{\prime} 33,8^{\prime \prime} \mathrm{S}, 50^{\circ} 25^{\prime} 22,5^{\prime \prime} \mathrm{W}\right)\end{array}$ & $\begin{array}{l}\text { Unshaded stream with } \\
\text { substrate composed of clay } \\
\text { and sand with a portion of } \\
\text { dead plant material and } \\
\text { macrophytes. }\end{array}$ \\
\hline $\begin{array}{l}\text { Site } 2 \text { - Água do Cervo } \\
\text { stream }\left(22^{\circ} 36^{\prime} 25,1^{\prime \prime} \mathrm{S},\right. \\
\left.50^{\circ} 25^{\prime} 52,7^{\prime \prime} \mathrm{W}\right)\end{array}$ & $\begin{array}{l}\text { Shaded stream with substrate } \\
\text { composed of sand and dead } \\
\text { plant material }\end{array}$ \\
\hline $\begin{array}{l}\text { Site } 3 \text { - Água da Porca } \\
\text { stream }\left(22^{\circ} 36^{\prime} 54,4^{\prime \prime} \mathrm{S},\right. \\
\left.50^{\circ} 25^{\prime} 00,5^{\prime \prime} \mathrm{W}\right)\end{array}$ & $\begin{array}{l}\text { Partially shaded stream with } \\
\text { substrate composed mainly of } \\
\text { pebbles, gravel and sand. }\end{array}$ \\
\hline
\end{tabular}

Branco \& Necchi Júnior 1997). Branco et al. (2008) proposed that, despite the relevance of regional variables, particular features of each stream can strongly influence the seasonal tendencies at a local scale. Branco et al. (2009) extended this concept and suggested that differences in diversity and distribution of macroalgal communities among streams could be explained by the combination of specific features in small sections (i.e., microhabitat scale) of each stream.

Therefore, the aim of the present study was to carry out comparisons among the structure of macroalgal communities over an entire year in three tropical streams in the Cervo River Basin, southeastern Brazil. Samples were taken monthly to assess the species richness and abundance of macroalgal communities and their relationships with environmental factors. We hypothesized, that differences in environmental variables at the local scale are important in controlling the distribution of lotic communities (Branco et al. 2008, 2009). We also expected that differences would be found for macroalgal seasonal fluctuations in each stream, since they have particular features, especially of light availability.

\section{Materials and methods}

\section{Study area}

The study was carried out in three streams (Table 1) belonging to the Cervo River Basin, a tropical drainage basin located in São Paulo State, southeastern Brazil. The region is broad and flattened, with straight sides, and altitudes ranging from 500 to 588 meters (Max et al. 2003). The climate condition is characterized as tropical with rainy summer and dry winter (Max et al. 2003). The original flora was Brazilian savanna, but the deterioration has replaced the original vegetation by sugarcane and reforestation of Pinus sp. and Eucalyptus sp.

\section{Sampling procedures and analysis}

The streams were sampled monthly from December 2005 to November 2006. Samples were taken by using the cross-transect technique (Branco et al. 2009). We divided the stream transect in 10 equal parts (1 m each) (Branco et al. 2009). Percent cover on the stream bottom was calculated by visual analysis for each $1 \mathrm{~m}$ interval and averaged for the whole $10 \mathrm{~m}$ transect (Branco et al. 2009). The specimens found throughout the study period were preserved in formaldehyde 4\% (Peres et al. 2008). We adopted the concept of macroalgae and respective morphological types as defined by Sheath \& Cole (1992).

At each sampling occasion, the water temperature, $\mathrm{pH}$, dissolved oxygen, turbidity and electric conductivity were measured in each site using a Horiba U-10 equipped with a multiparameter probe $\left(\right.$ Horiba $^{\circledR}$, Kyoto, Japan). Irradiance was measured using a quantometer LI-250 (Li-Cor ${ }^{\circledR}$, Lincoln, USA). The current velocity was recorded using an electronic flowmeter Swoffer 3000 (Swoffer Instruments ${ }^{\circledR}$, Seattle, USA), while depth was measured by a ruler. To obtain the nutrients concentration, a sample of water was collected and frozen immediately. Table 2 summarizes all environmental factors collected in each stream.

Table 2. Environmental variables measured at each sampling sites at the River Cervo Basin.

\begin{tabular}{|c|c|c|c|}
\hline Variables & Site 1 & Site 2 & Site 3 \\
\hline \multirow[t]{2}{*}{ Temperature $\left({ }^{\circ} \mathrm{C}\right)$} & $17.6-28.8$ & $16.3-27.9$ & $15.6-26.0$ \\
\hline & $23.9 \pm 3.9$ & $22.2 \pm 4.1$ & $21.5 \pm 3.8$ \\
\hline \multirow[t]{2}{*}{ Conductivity $\left(\mu \mathrm{S} . \mathrm{cm}^{-1} \cdot \mathrm{s}^{-1}\right)$} & $4.0-310.0$ & $4.0-28.0$ & $4.0-9.0$ \\
\hline & $46.6 \pm 90.3$ & $7.3 \pm 6.9$ & $5.6 \pm 1.9$ \\
\hline \multirow[t]{2}{*}{ Turbidity (NTU) } & $5-24$ & $2-15$ & $7-15$ \\
\hline & $9.2 \pm 9.0$ & $6.0 \pm 3.6$ & $10.1 \pm 2.3$ \\
\hline \multirow[t]{2}{*}{ Dissolved Oxygen (mg. $\left.\mathrm{L}^{-1}\right)$} & $4.6-6.6$ & $4.7-7.0$ & $4.9-7.7$ \\
\hline & $5.6 \pm 0.7$ & $5.7 \pm 0.7$ & $6.2 \pm 0.8$ \\
\hline \multirow[t]{2}{*}{ pH } & $5.0-6.6$ & $5.5-6.1$ & $5.4-6.1$ \\
\hline & $6.0 \pm 0.5$ & $5.8 \pm 0.2$ & $5.7 \pm 0.2$ \\
\hline \multirow[t]{2}{*}{ Depth (cm) } & $18.6-27.6$ & $24.9-35.1$ & $29.8-38.0$ \\
\hline & $21.9 \pm 2.9$ & $29.0 \pm 3.6$ & $32.6 \pm 2.8$ \\
\hline \multirow[t]{2}{*}{ Current Velocity $\left(\mathrm{cm}^{-\mathrm{s}^{-1}}\right)$} & $22.0-71.0$ & $16.7-40.9$ & $39.0-65.0$ \\
\hline & $39.0 \pm 16.1$ & $24.7 \pm 6.9$ & $52.3 \pm 7.8$ \\
\hline \multirow[t]{2}{*}{ Irradiance $\left(\mu \mathrm{mol} \cdot \mathrm{m}^{-2} \cdot \mathrm{s}^{-1}\right)$} & $104.4-1391.2$ & $5.6-210.7$ & $30.4-420.8$ \\
\hline & $701.9 \pm 436.4$ & $43.1 \pm 57.6$ & $175.5 \pm 129.6$ \\
\hline \multirow[t]{2}{*}{ Total Nitrogen $\left(\mathrm{mg} . \mathrm{L}^{-1}\right)$} & $0.1-0.7$ & $0.1-0.7$ & $0.1-0.5$ \\
\hline & $0.38 \pm 0.32$ & $0.16 \pm 0.30$ & $0.28 \pm 0.21$ \\
\hline \multirow{2}{*}{ Total Phosporus (mg. $\mathrm{L}^{-1}$ ) } & $0.11-0.21$ & $0.10-0.22$ & $0.13-0.23$ \\
\hline & $0.16 \pm 0.04$ & $0.16 \pm 0.04$ & $0.16 \pm 0.03$ \\
\hline
\end{tabular}

Values represent minimum and maximum range, average, and standard deviation $(n=12)$ 
Spatial and temporal distribution of stream macroalgae in a tropical river basin

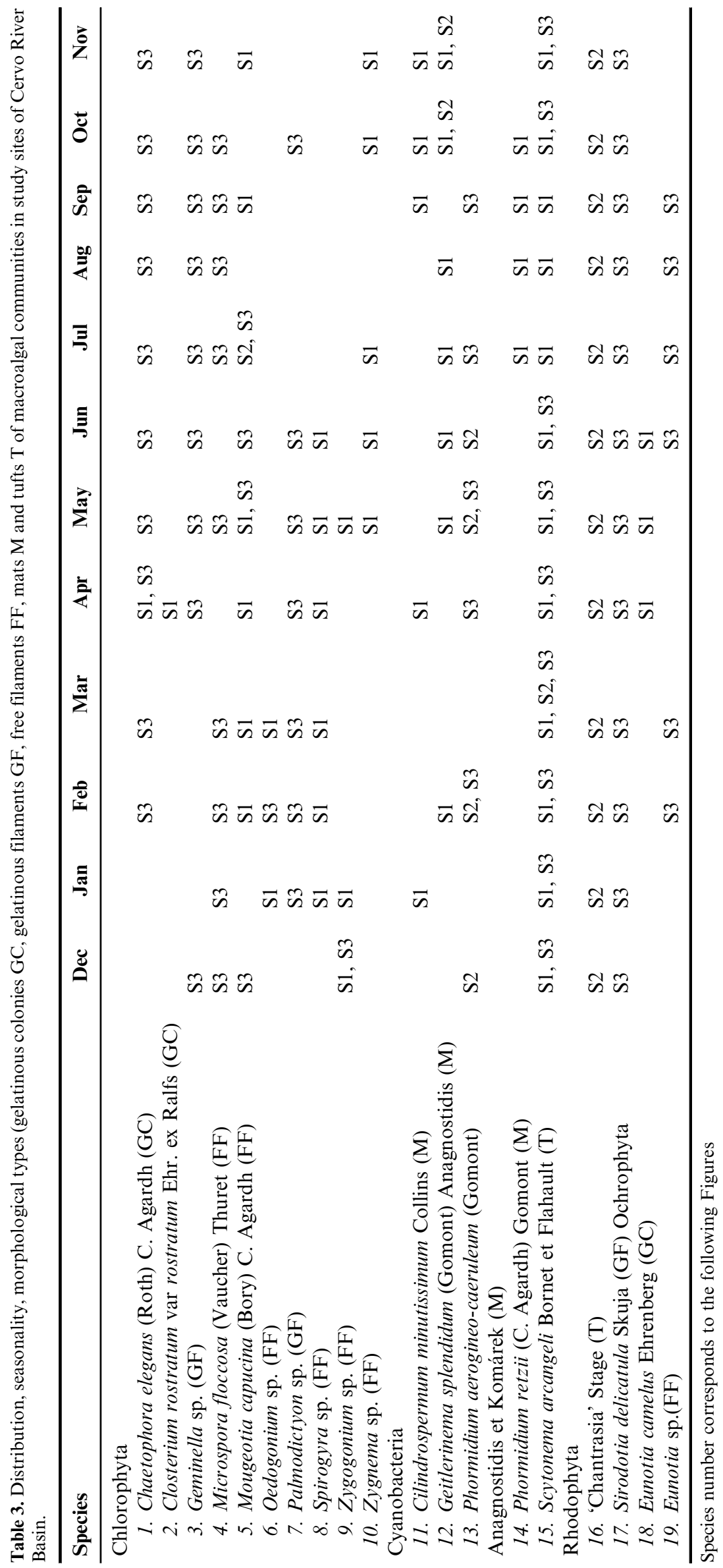


Microscopic observations and morphometric analysis of specimens were performed using an optical microscopy, Leica DM-1000 (Leica Microsystems GmbH, Wetzlar, Germany), coupled with an image capture system for species identification in laboratory. To quantify nutrients (total nitrogen and total phosphorus) we used a spectrophotometer, Merck, model Spectroquant Nova 60, with specific kits for each nutrient. Finally, rainfall data were obtained from the pluviometric station of Assis, the closest weather station from the sampling sites.

\section{Data analyses}

Dominance-diversity curves were constructed based on abundance (i.e., percent cover) of macroalgae to analyze differences in richness and abundance among sampling sites and among sampling dates. The relationship among spatial and temporal distribution of macroalgal abundance with environmental factors was assessed using CCA (Canonical Correspondence Analysis), followed by Monte Carlo test (999 permutation, $\alpha=0.05$ ) to determine the results significance. These statistical analyses were performed using PC-ORD version 5.31. In addition, we applied a cluster analysis to verify the similarity of the species composition among the studied streams using the statistical software NTSYS, version 2.1.

\section{Results}

\section{Analysis of macroalgal communities}

A total of 19 taxa were recorded from the three streams (Table 3), of which eight were identified only to generic level (including sterile green algae, three possibly new species and the sporophytic stage of Sirodotia, the 'Chantransia' stage) and 11 to infrageneric level. Chlorophyta had greatest representation with 10 taxa $(52.7 \%$ of total), followed by Cyanobacteria with five $(26.3 \%)$, and Ochrophyta and Rhodophyta with two each $(10.5 \%)$. The proportion of macroalgal morphological types was as follows: free filaments ( 7 taxa $-36.8 \%$ of total), mats $(4-21 \%)$, gelatinous filaments $(3-15.8 \%)$, gelatinous colonies $(3-15.8 \%)$ and tufts $(2-10.5 \%)$. Among the taxa identified, $13(68.4 \%$ of total) were collected in a single sampling site. Closterium rostratum was reported once in one sampling site, while Scytonema arcangeli and Mougeotia capucina were recorded several times in all sampling sites. $S$. arcangeli had the highest number of records, totalizing 23 occurrences $(63.6 \%$ of the sampling dates).

Species richness, abundance and morphological types showed pronounced differences among sites and sampling dates (Table 3, Figures 1-3). In the sampling site 1 (S1), we recorded a relative richness varying from two to seven species per sampling dates associated with the highest mean value of macroalgal percent cover $(12 \%)$ among the studied streams. In turn, the sampling site 3 (S3) had the highest relative richness of species per date (4-8) and intermediate mean value of percent cover $(5.9 \%)$. In sampling site $2(\mathrm{~S} 2)$, on the other hand, were found the lowest relative richness (1-3) and the lowest mean percent cover value $(0.8 \%)$.

Dominance-curves (Figures 1-3) showed the dominance of one or few species in all sampling sites and sampling dates, with dominant species varying among sampling sites and sampling
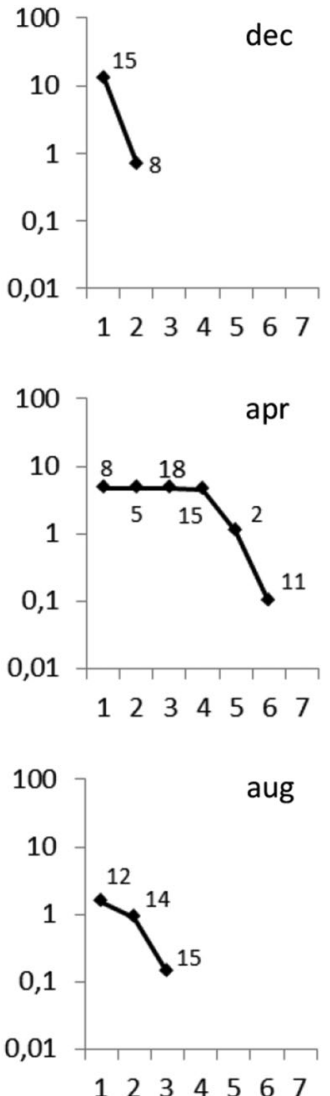
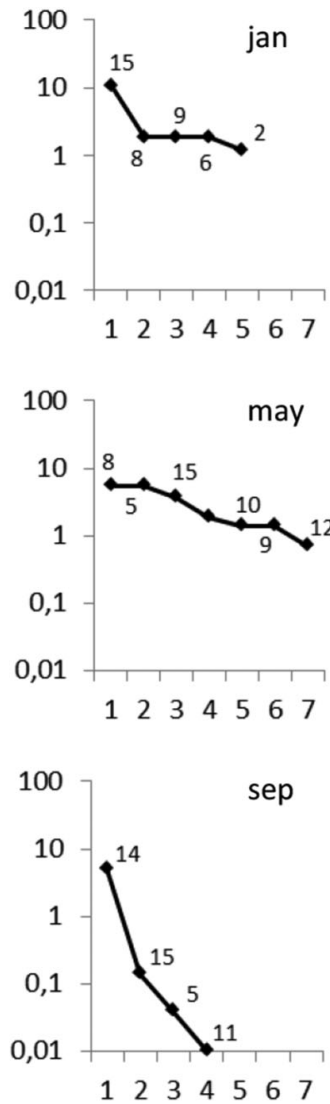
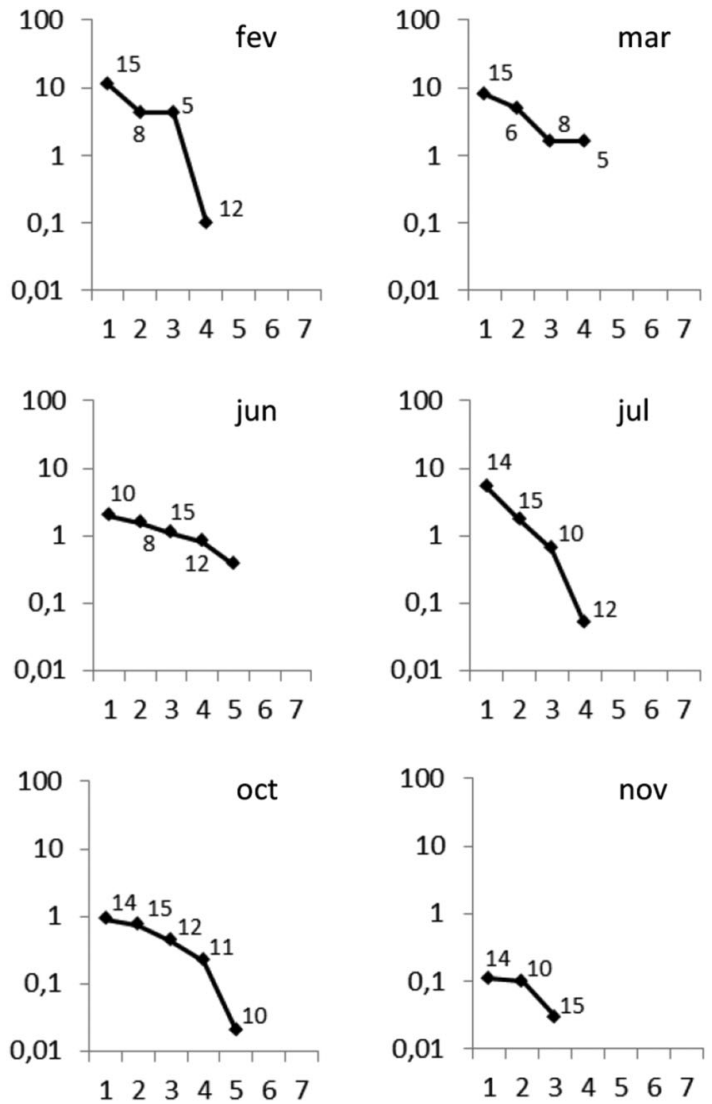

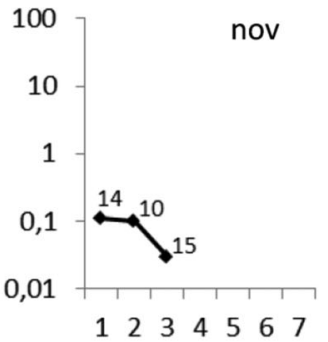

Figure 1. Dominance-diversity curves based on macroalgal percent cover between months in Site 1 . The horizontal axis represent the percent cover and the vertical axis the number of species. 

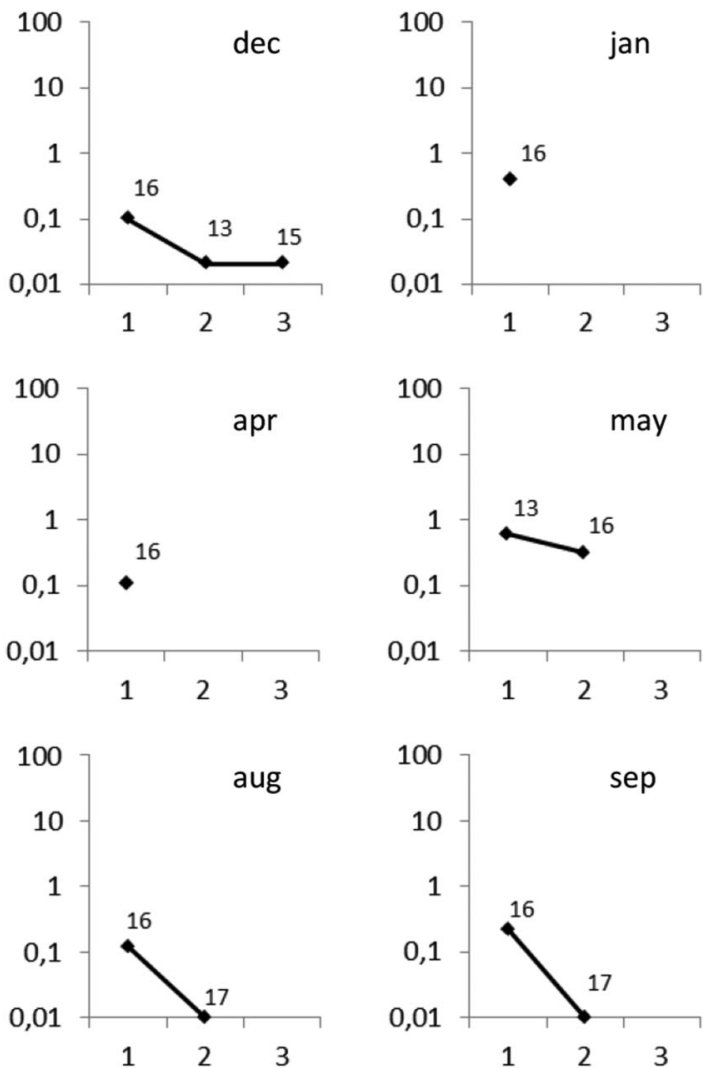
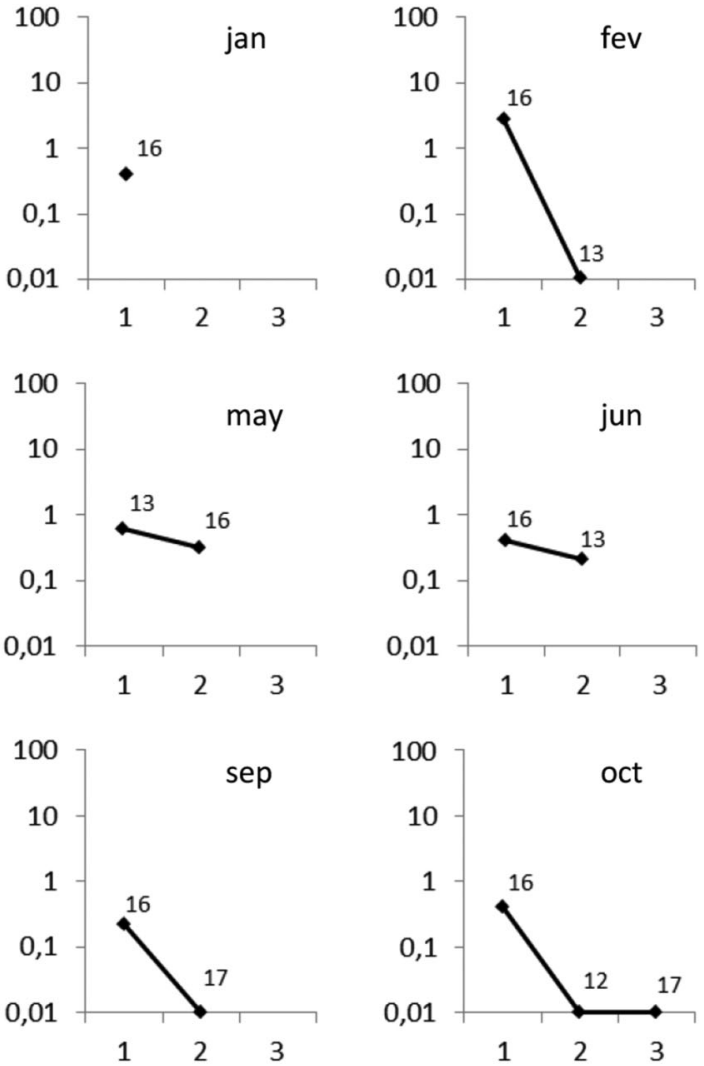
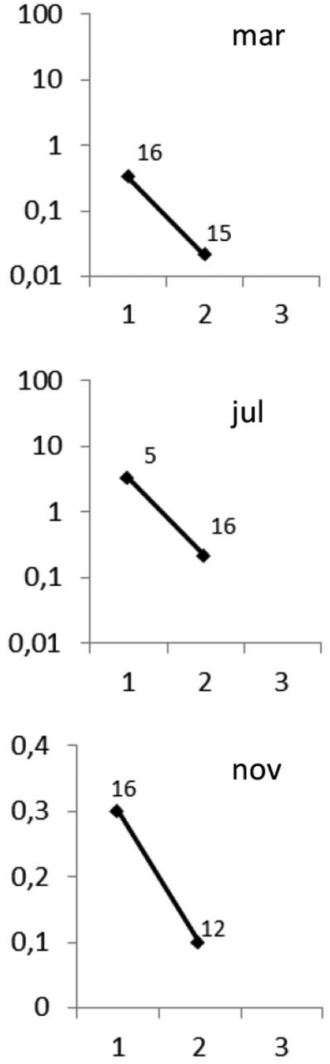

Figure 2. Dominance-diversity curves based on macroalgal percent cover between months in Site 2 . The horizontal axis represent the percent cover and the vertical axis the number of species.

dates. In S1 (Figure 1), the dominant specie varied through time, with predominance of Scytonema arcangeli at the beginning of the samplings (December/2005 to March/2006), but the dominance changed to Spyrogyra sp. in the intermediate sampling dates (April to June/2006) and changed again to Phormidium retzii from July until the end of the samplings (July to November/2006). In the S2 (Figure 2), 'Chantransia' stage was the predominant species in ten of the twelve sampling dates (83.3\%). In the S3 (Figure 3), after April/2006, Sirodotia delicatula was definitively established as the dominant species and remained so until the end of the sampling period.

Differences in specific composition among sampling dates were recorded for all sampling sites, however, despite the dominance observed, associations of few species were registered for the three streams year around. Thus, for S1, S. arcangeli and Spirogyra sp. were frequently associated, while for S2, 'Chantransia' and Phormidium aerogineo-caeruleum varied their abundance in relative synchrony and for S3, the same situation was observed but with Sirodotia delicatula and Microspora floccosa.

Considering species composition similarity among sampling sites, the cluster analysis revealed small similarity among them (20-26\% of similarity), reflecting the fact that only 2 species have been recorded in all three sampling sites. The seasonal fluctuation of macroalgal communities abundances varied from stream to stream. Thus, in S1 was observed higher macroalgal percent cover from December to May (summer-spring), a period with higher occurrence of rains in tropical regions, while, in S2 and S3 no evident seasonal variation pattern was identified.

\section{Relationship among macroalgal distribution and environmental factors}

In the CCA, the first two axes explained $37.8 \%$ of the total variation in macroalgal distribution, with first axis being significant $(P=0.001)$ (Figure 4$)$. The relationship between species and environmental factors was significant to axis one $(P=0.001)$, showing that irradiance, current velocity, substrate and depth were the variables that more contributed to explain the spatial distribution of macroalgal species and the grouping of streams. Moreover, this analysis revealed that sampling sites were grouped mainly by spatial features (including the particularity in species composition and environmental variables), rather than by temporal characteristics. Thus, Figure 4 showed the formation of three groups, representing the complete set of the sampling dates of S1, S2 and S3. The CCA analysis also showed that sampling dates of the S2 group had a more pronounced scattering along the environmental gradient than the sampling dates of the other two groups, S1 and S3 (Figure 4).

Considering streams individually, CCA revealed that the first axis was significant for $\mathrm{S} 1(P=0.013)$, and the two first axes explained $48.4 \%$ of the total variation in macroalgal abundance. In this sampling site, species distribution was mainly determined by irradiance, dissolved oxygen, temperature, water velocity and precipitation (Figure 5, S1). The CCA analysis of the sampling sites S2 and S3 revealed no significant relationships $(P>0.05)$ among axes and species distribution for these streams (Figure 5, S2 and S3). 
Tonetto, A.F. et al.
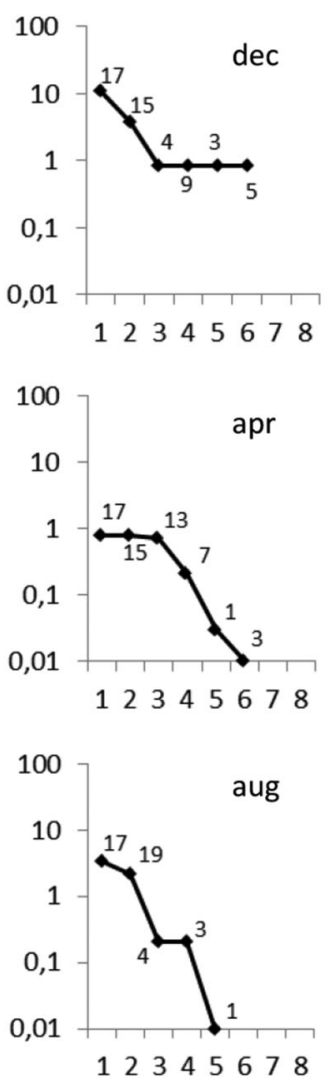
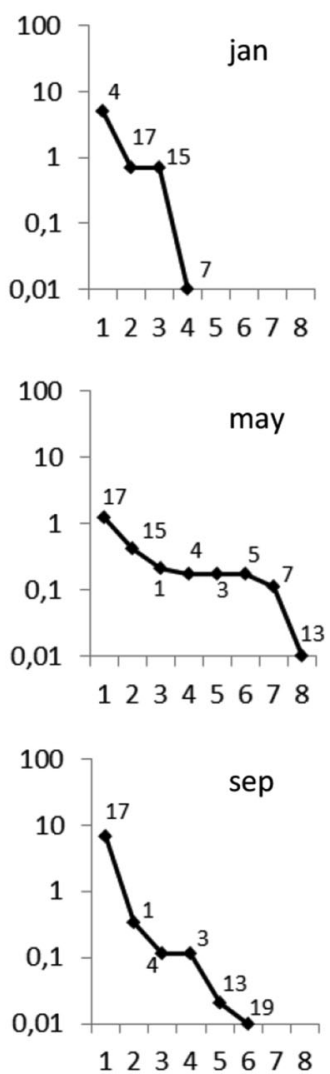
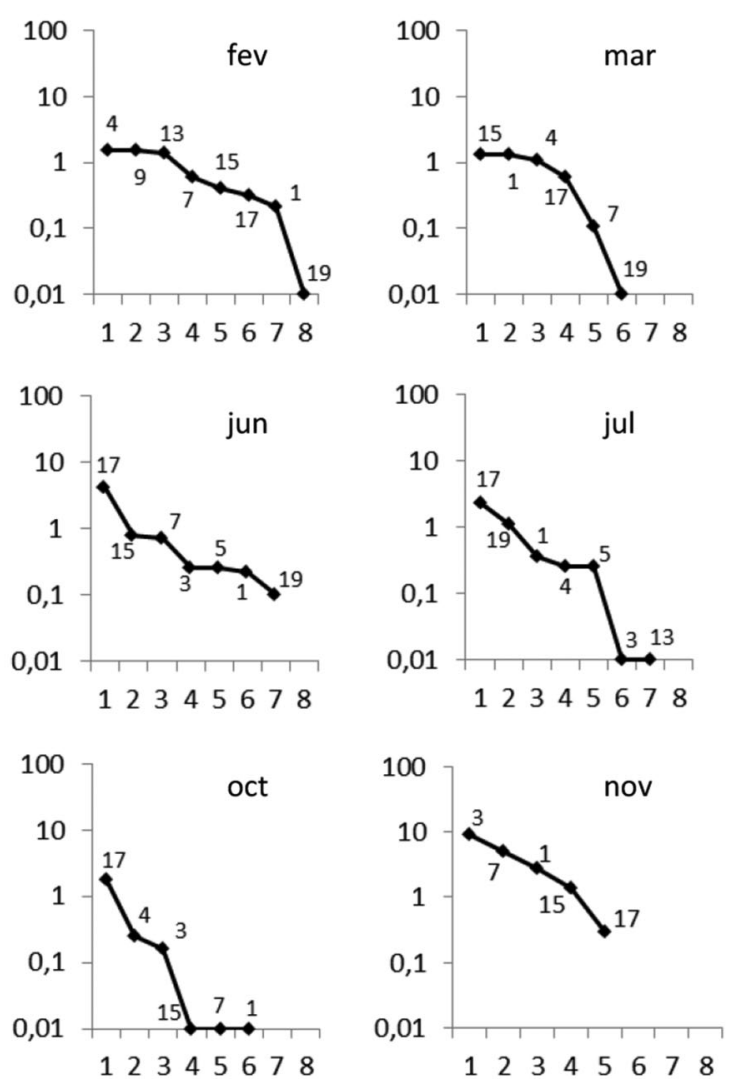

Figure 3. Dominance-diversity curves based on macroalgal percent cover between months in Site 3 . The horizontal axis represent the percent cover and the vertical axis the number of species.

\section{Discussion}

The mean species richness per sampling site ranged from five to 11 taxa, what is expected for tropical streams (Necchi Júnior et al. 1991, Branco \& Necchi Júnior 1996, Branco et al. 2008). In each sampling site, the absolute number of species ranged between one and eight (mean $=4.0 \pm 2.2$ ) and also is in accordance with the pattern frequently found in similar studies conducted in tropical regions $(2.5 \pm 1.6$ - Branco \& Necchi Júnior 1996, $2.6 \pm$ 1.5 - Krupek et al. 2007, $2.6 \pm 1.6$ - Branco et al. 2008, $4.2 \pm 2.3$ - Necchi Júnior et al. 2008, and $6.7 \pm 2.7$ - Necchi Júnior et al. 2003). Likewise, the macroalgal abundance (in terms of percent cover) of each sampling site varied from 0.11 to $20.4 \%(6.4 \% \pm$ 6.8), which is similar to other previous studies (e.g. $5.2 \pm 8.4-$ Krupek et al. 2007, $5.7 \pm 7.4-$ Branco et al. 2008, $13.5 \pm 11.9-$ Necchi Júnior et al. 2008, and $15.4 \pm 21.0$ - Branco \& Necchi Júnior 1996).

Chlorophyta was the algal group that showed the highest total number of species. However, members of Cyanobacteria ( $S$. arcangeli and Phormidim retzii, in S1) and Rhodophyta ('Chantransia' in S2 and Sirodotia delicatula in S3) were dominant in terms of percent cover in the three streams investigated. DeNicola et al. (1992) states that the lack of pigment diversity in Chlorophyta limits their establishment and distribution to stream sections with high irradiance. Some of our results seem to confirm this hypothesis. For instance, Mougeotia capucina was widely recorded in streams with higher light availability (sampling sites $\mathrm{S} 1$ and $\mathrm{S} 3$ ) in Cervo River Basin, while this species was registered only once in the heavily shaded stream (sampling site S2). Cyanobacteria and Rhodophyta, on the other hand, have a pigment complex that allows them to tolerate low irradiances.
Necchi Júnior et al. (2008) reported the presence, sometimes predominant, of Cyanobacteria species in lotic environments with varying degree of shading, ranging from open to heavily shaded streams. Nonetheless, Branco \& Necchi Júnior (1996) reported a relative predominance of red algae in shaded and heavily shaded streams from the Brazilian Atlantic Forest. Hence, we believe that the pigment content of cyanobacteria and red algae may have favored these algal phyla, what could explain their greater abundance in the studied streams.

The stream environmental features had a relative influence in temporal and spatial distribution of macroalgal communities. However, considering present and previous studies (see Introduction section), it is difficult to precisely identify what stream variable is more important for macroalgae because numerous variables have been considered as relevant for their distribution. Indeed, several researchers have suggested that the relationship between the ecological distribution of these organisms and environmental characteristics must be examined carefully (Krupek et al. 2007, Branco et al. 2009). Despite this difficulty, in our study, the availability of light in each stream seemed to affect macroalgal communities variability (as showed by CCA groups), followed by physical and chemical characteristics of each sampling site. Thus, we suggest that the primary environmental filter is the type of riparian vegetation, what determines the initial establishment of stream macroalgal communities. Secondarily, other stream variables could be relevant for the development and maintenance of these organisms. For instance, in S2 and S3, where availability of light was reduced, irradiance was so limiting for macroalgal growth (low values of macroalgal percent cover) that no other local environmental factors had significant influence on the macroalgal distribution (Krupek et al. 2007, Peres et al. 2009), 


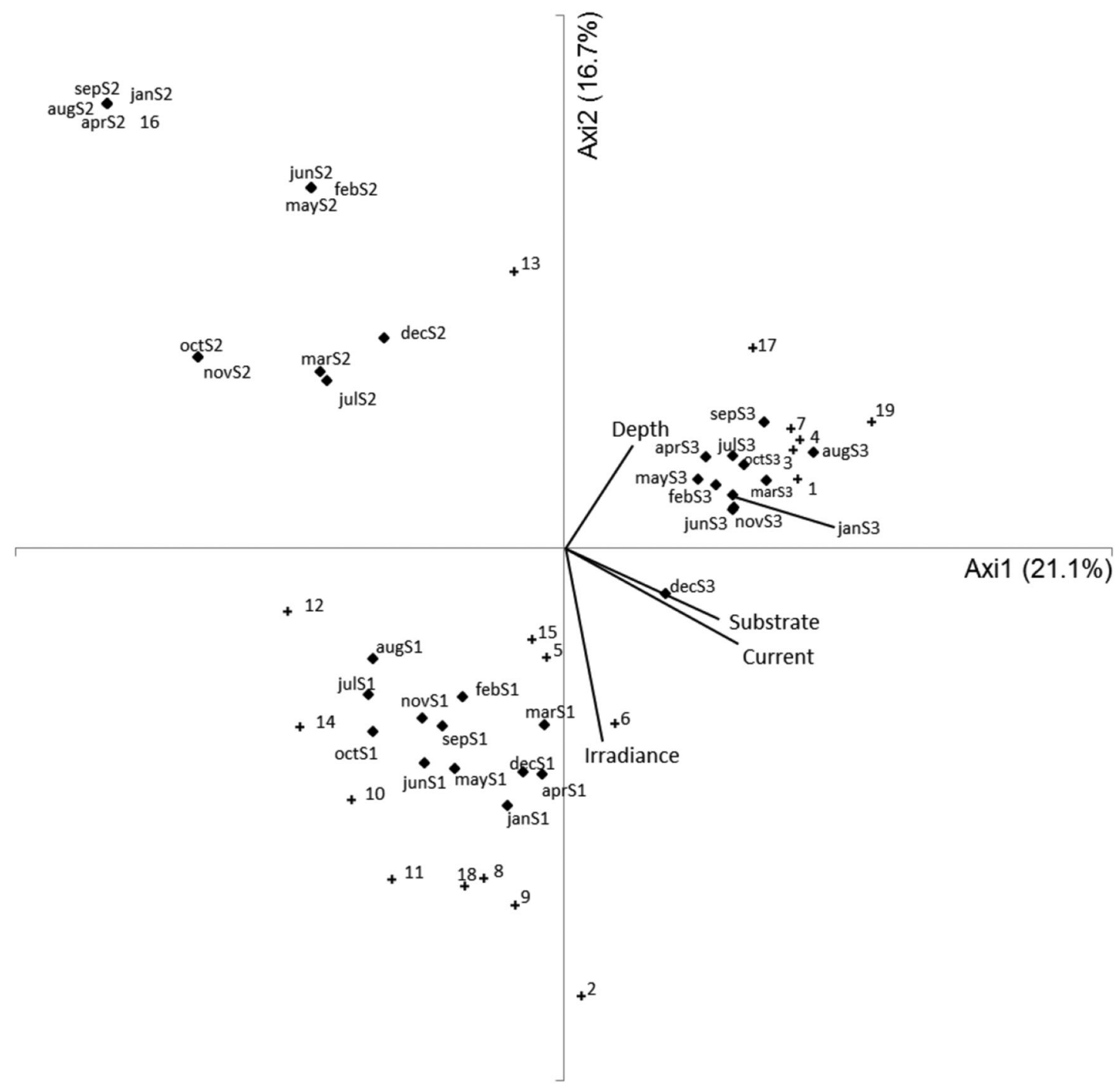

Figure 4. CCA biplot of the general distribution of sites and macroalgae with regard to environmental factors recorded in all study. Cross corresponds to species, $\mathrm{S} 1, \mathrm{~S} 2$ and $\mathrm{S} 3$ is site abbreviation.

as showed by CCA analyses. On the other hand, in S1 where irradiance registered higher values, the macroalgal development was also significantly higher than the other two streams investigated (as showed by higher values of macroalgal percent cover). In this condition of light availability, other local environmental variables (e.g., dissolved oxygen and temperature) have gained significant influence on the communities distribution (Branco et al. 2009, Costa \& Mello 2008).

Considering macroalgal flora, we observed a clear distinction in community composition among the streams. This difference seems to be a consequence of variances in light availability at each sampling site. According to CCA (Figure 4), the sampling site with lower irradiance (S2) showed a much more dissimilar community than those sampling sites with higher light availability (S1 and S3). Considering that light limitation on algal growth has been extensively documented (e.g., Tonetto et al. 2012) and, that different species have distinct ecophysiological abilities to absorb light, we believe that community composition found in S2 was basically influenced by a pool of species adapted to habitats with lower levels of irradiance (Stevenson 1996). Indeed, in S2 we reported a few number of species per sampling date and, individually, the species showed low reoccurrence, being recorded only in one or few samples (e.g., Mougeotia capucina that appeared only in July, Sirodotia delicatula in August, and Geitlerinema splendidum in October. For this reason, S2 exhibited a higher variation in species composition through time. In addition, we suggest that this site is composed by macroalgal species that require more specific conditions and, therefore, they suffer great impact from abiotic oscillations (Pandit et al. 2009) providing this variability in community composition.

On the other hand, S1 and S3 had a higher and intermediate light condition and, consequently supported a higher percent cover and number of species. Due to high availability of irradiance, communities can reach higher abundance and maintain themselves in a more stable condition through time. Seasonality, gain and loss of species would provide few changes in community composition. Thus, in general, streams with low supply of light will present a lower number of species, and a more unstable community through time than communities from streams with higher availability of light. 
Tonetto, A.F. et al.

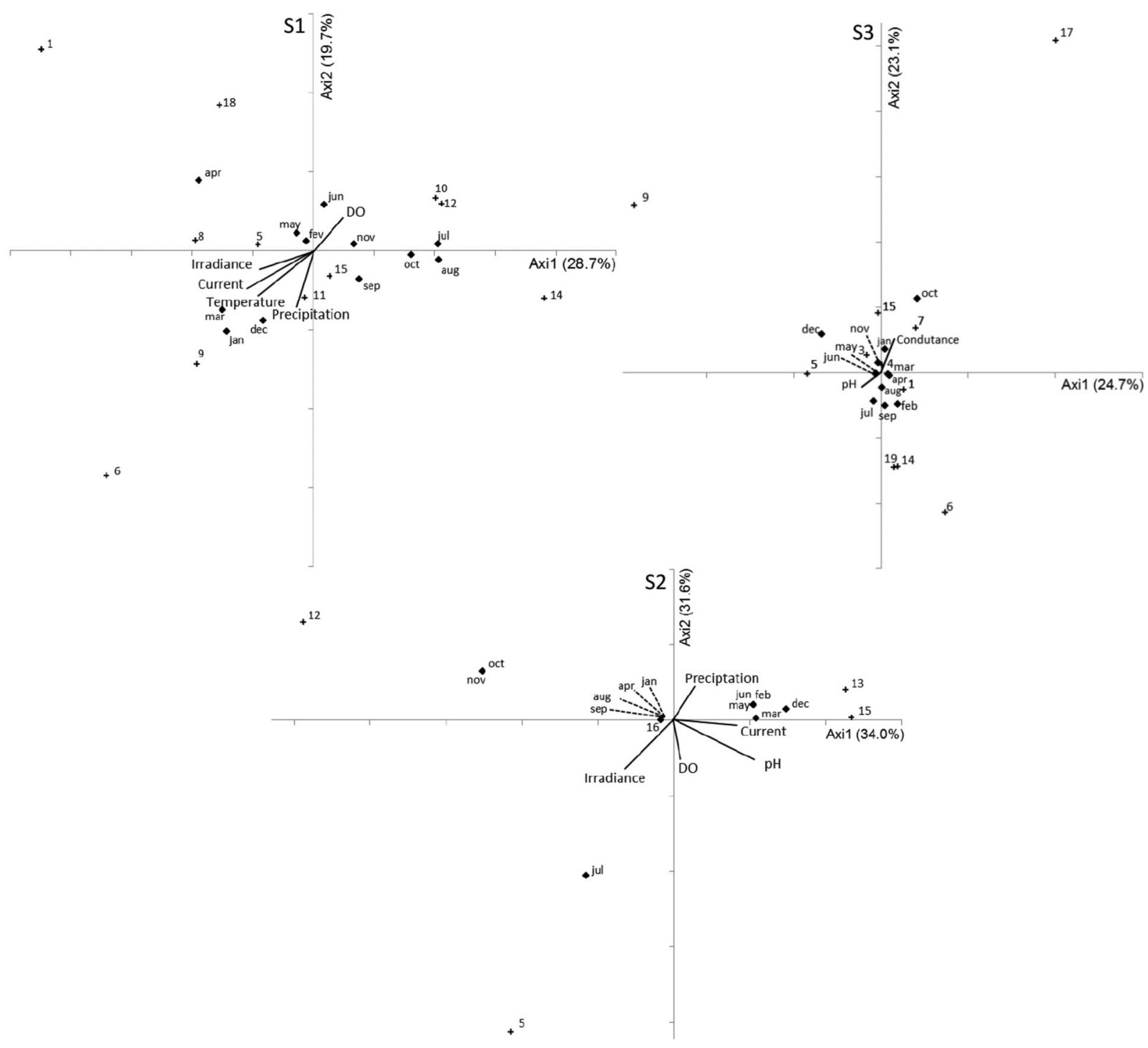

Figure 5. CCA biplot of the general distribution of macroalgae according to environmental factors registered in each site. Cross corresponds to species, Black diamond corresponds to months.

The three sampling sites showed strong dominance of few species with common species being reported throughout year (e.g. Scytonema arcangeli at S1, 'Chantransia' at S2, and Sirodotia delicatula at S3). Indeed, these results are in agreement with one of the most important ecological observations in nature which states that most natural communities are composed by few common species and many rare species (Siqueira et al. 2012). In addition, we reported only two species occurring in all three sampling sites (Scytonema arcangeli and Mougeotia capucina). Indeed, this type of species occurrence is very common in ecological studies focusing on lotic macroalgal communities (Branco et al. 2009, Hu \& Xie 2006, Peres et al. 2010), where one species is frequently reported in only one stream, even under broad geographical bases. Because of this particular pattern of ecological distribution, the spatial and temporal variations in the macroalgal communities become difficult to describe, since the species sampling may not represent the real community composition because of rarity.

In conclusion, our results showed that the light availability has a central role in spatial and temporal variations of lotic macroalgal communities. Even with this information, a precise description of seasonal pattern of macroalgae in relation to environmental factors remains very difficult to be described, especially for tropical streams where rare species represent an important part of the communities' composition. Furthermore, our data support the hypothesis that local characteristics of each stream segment influence the ecological distribution of macroalgae (Branco et al. 2008, Costa \& Melo 2008, Branco et al. 2009). We finally suggest that studies on micro and/or mesohabitat scales of analysis can be fundamental to better understand the ecological distribution of these communities.

\section{References}

ALLAN, J.D. \& CASTILLO, M.M. 2007. Stream ecology: structure and function of running waters. Chapman and Hall, New York.

BOJORGE-GARCIA, M., CARMONA, R., BELTRÁN, Y. \& CARTAJENA, M. 2010. Temporal and spatial distribution of macroalgal commnunities of mountain streams in Valle de Bravo 
Basin, central Mexico. Hydrobiologia 641: 159-169, http://dx.doi.org/ 10.1007/s10750-009-0074-5

BORCHARDT, M.A. 1996. Nutrients. In Algal ecology (R.J. Stevenson, M.L. Bothwell \& R.L. Lowe, eds). Academic Press, San Diego. p. 184-227.

BRANCO, C.C.Z., KRUPEK, R.A. \& PERES, C.K. 2008. Seasonality of macroalgal communities in a subtropical drainage basin in Paraná State, southern Brazil. Braz. J. Biol. 68:741-749, http://dx.doi.org/ 10.1590/S1519-69842008000400008

BRANCO, C.C.Z., KRUPEK, R.A. \& PERES, C.K. 2009. Distribution of stream macroalgal communities from the mid-western region of Paraná State, southern Brazil: Importance of local scale variation. Braz. Arch. Biol. Techn. 52:379-386, http://dx.doi.org/ 10.1590/S1516-89132009000200015

BRANCO, C.C.Z. \& NECCHI JÚNIOR, O. 1996. Distribution of stream macroalgae of eastern Atlantic Rainforest of São Paulo State, Southeastern Brazil. Hydrobiologia 333:139-150, http://dx.doi.org/ 10.1007/BF00013428

BRANCO, L.H.Z. \& NECCHI JÚNIOR, O. 1997. Seasonality of macroalgae in three tropical drainage basins in São Paulo State, southeastern Brazil. Arch. Hydrobiol. 141:75-91.

COSTA, S.S. \& MELO, A.S. 2008. Beta diversity in stream macroinvertebrate assemblages: among-site and among-microhabitat components. Hydrobiologia 598:131-138, http://dx.doi.org/10.1007/ s10750-007-9145-7

DeNICOLA, D.M. 1996. Periphyton responses to temperature at different ecological levels. In Algal ecology (R.J. Stevenson, M.L. Bothwell \& R.L. Lowe, eds). Academic Press, San Diego. p. 150-181.

DeNICOLA, D.M., HOGLAND, K.D. \& ROEMER, S.C. 1992. Influence of canopy cover on spectral irradiance and periphyton assemblages in a prairie stream. J. N. Am. Benthol. Soc. 11:391-404, http://dx.doi.org/10.2307/1467560

HU, B.F. \& XIE, S.L. 2006. Effect of seasonality on distribution of macroalgae in a stream system (Xin'an Spring) in Shanxi Province, North China. J. Integr. Plant Biol. 48:889-896, http://dx.doi.org/ 10.1111/j.1744-7909.2006.00317.x

KRUPEK, R.A., BRANCO, C.C.Z. \& PERES, C.K. 2007. Distribuição ecológica das comunidades de macroalgas da bacia de drenagem do Rio das Pedras, região Centro-Sul do Estado do Paraná, Sul do Brasil. Braz. J. Bot. 30:173-182, http://dx.doi.org/ 10.1590/S0100-84042007000200002

MAX, J.C.M., MELO, A.C.G., HONDA, E.A., DURIGAN, G., MALÍCIA, L.C., SOUZA, M.B.M., CARDOSO, M.M., BOAS, O.V. \& RAMOS, V.S. 2003. Plano de manejo da Floresta Estadual de Assis. Instituto Florestal, São Paulo.

NECCHI JÚNIOR, O, BRANCO, C.C.Z. \& BRANCO, L.H.Z. 2000. Distribution of stream macroalgae in São Paulo State, southeastern Brazil. Algol. Stud. 97:43-57.

NECCHI JÚNIOR, O, BRANCO, L.H.Z. \& BRANCO, C.C.Z. 2003. Ecological distribution of stream macroalgal communities from a drainage basin in the Serra da Canastra National Park, Minas Gerais, Southeastern Brazil. Braz. J. Biol. 63:1-12, http://dx.doi.org/ 10.1590/S1519-69842003000100002

NECCHI JÚNIOR, O., BRANCO, L.H.Z. \& SPEZAMIGLIO, D.N. 2008. Distribuição ecológica de comunidades de macroalgas de ambientes lóticos do Parque Nacional de Itatiaia (RJ, MG), Brasil. Revista Braz. J. Bot. 31:135-145.

NECCHI, O., DIP, M.R. \& Góes, R.M. 1991. Macroalgae of streams in southeastern Brazil: composition, seasonal variation and relation to physical and chemical variables. Hydrobiologia 213: 241-250, http://dx.doi.org/10.1007/BF00016425

NECCHI JÚNIOR, O. \& PASCOALOTO, D. 1993. Seasonal dynamics of macroalgal communities of the Preto River Basin, São Paulo, southeastern Brazil. Arch. Hydrobiol. 129: 231-252.

PANDIT, S.N., KOLASA, J. \& COTTENIE, K. 2009. Contrasts between habitat generalists and specialists: an empirical extension to the basic metacommunity framework. Ecology 90: 2253-2262, http://dx.doi.org/10.1890/08-0851.1

PERES, C.K., BRANCO, C.C.Z. \& KRUPEK, R.A. 2008. Macroalgas de riachos da Serra da Prata, leste do Estado do Paraná, Sul do Brasil.Acta Bot. Bras. 22:333-344, http://dx.doi.org/10.1590/ S0102-33062008000200004

PERES, C.K., BRANCO, C.C.Z. \& KRUPEK, R.A. 2009. Distribuição ambiental e temporal das comunidades de macroalgasde riachos da Serra da Prata, Estado do Paraná, Sul do Brasil. Braz. J. Bot. 32: 625-633, http://dx.doi.org/10.1590/S0100-84042009000400002

PERES, C.K., BRANCO, C.C.Z. \& KRUPEK, R.A. 2010. Longitudinal distribution and seasonality of macroalgae in a subtropical stream impacted by organic pollution. Acta Limnol. Bras. 22:199-207, http://dx.doi.org/10.1590/S2179-975X2010000200009

SHEATH, R.G. \& COLE, K.M. 1992. Biogeography of stream magroalgal in North America. J. Phycol. 28:448-460, http://dx.doi.org/ 10.1111/j.0022-3646.1992.00448.x

SIQUEIRA, T., BINI, L.M., ROQUE, F.O., COUCEIRO, S.R.M., STRIXINO, S.T. \& COTTENIE, K. 2012. Common and rare species respond to similar niche process in macroinvertebrates metacommunities. Ecography 35:183-192, http://dx.doi.org/10.1111/ j.1600-0587.2011.06875.x

STEVENSON, R.J. 1996. An introduction to algal ecology in freshwater benthic habitats. In Algal ecology (R.J. Stevenson, M.L. Bothwell \& R.L. Lowe, eds). Academic Press, San Diego. p. 3-30, http://dx.doi.org/10.1016/B978-012668450-6/50030-8

TONETTO, A.F., BRANCO, C.C.Z. \& PERES, C.K. 2012. The effects of irradiance and spectral composition on the establishment of macroalgae in streams Ann. Limnol.-Int. J. Lim. 48:363-370, http://dx.doi.org/10.1051/limn/2012027

UEHLINGER, U. 1991. Spatial and temporal variability of the periphyton biomass in a prealpine river (Necker, Switzerland). Arch. Hydrobiol. 123:219-237. 